\title{
IL1B Gene
}

National Cancer Institute

\section{Source}

National Cancer Institute. IL1B Gene. NCI Thesaurus. Code C28593.

This gene is involved in the mediation of acute phase inflammatory responses. 